\title{
Micronutrients and anti-nutritional contents of selected tropical vegetables grown in SouthEast, Nigeria
}

\author{
Chinma, C.E ${ }^{1 *}$ and Igyor, M.A ${ }^{2}$ \\ ${ }^{1}$ Department of Food Science and Nutrition, Federal University of Technology, Minna, Nigeria \\ ${ }^{2}$ Department of Food Science and Technology Federal University of Agriculture, Makurdi, Nigeria \\ *Address for correspondence: Email: chinmachiemela@ yahoo.com.
}

\begin{abstract}
Levels of some nutrients and antinutrients of six green leafy vegetables grown in SouthEast, Nigeria were determined using standard analytical methods Crude protein, fat, moisture, crude fiber carbohydrate and calorific values ranged from 1.20 to $2.20 \mathrm{~g} / 100 \mathrm{~g}, 0.80$ to $1.30 \mathrm{~g} / 100 \mathrm{~g}, 74$ to $93 \%, 0.70$ to $2.10 \mathrm{~g} / 100 \mathrm{~g}, 1.30$ to $13.20 \mathrm{~g} / 100 \mathrm{~g}$ and 21.00 to $97.00 \mathrm{kcal} / 100 \mathrm{~g}$. The vitamin $\mathrm{C}$ composition varied from 14.61 to $30.84 \mathrm{mg}$. The elemental analysis of the six leaves in mg dry matter indicated that the leaves contained appreciable levels of iron (3.43 to 23.03), calcium (204.26 to 305.51 and magnesium (195.57 to 340.39).
\end{abstract}

ABSTRACT

The antinutrient composition for phytic acid, tannins and oxalic acid are; 34.70 to $68.50 \mathrm{mg} / 100 \mathrm{~g}, 0.32$ to $0.83 \mathrm{~g} /$ $100 \mathrm{~g}$ and 24.65 to $42.15 \mathrm{mg} / \mathrm{g}$ respectively. These results reveal that those leaves contain an appreciable amount of nutrient, vitamin, mineral elements and low level of toxicants and should be included in diets to supplement our daily allowance needed by the body.

Keywords: Leafy vegetables, vitamin, minerals and antinutrients.

\section{INTRODUCTION}

$\mathbf{T}$ The importance and awareness of nutrition in public health issues has resulted in the increased demand of knowledge of the nutrient of food. Green leafy vegetables occupy an important place among the food crops as they provide adequate amounts of many vitamins and minerals for humans. They are rich sources of carotene, ascorbic acid, riboflavin, folic acid and minerals like calcium, iron and phosphorus (Fasuyi, 2006). In addition, they contain antinutrents which reduce their bioavailability (Akindahunsi and Salawu, 2005). (Aletor and Adeogun 1995) reported that some antinutritional phytochemicals exhibit protective effects, thus making them to serve a dual purpose of reducing some essential nutrients and protecting the body against a number of biochemical, physiological and metabolic disorders.

Several vegetable specie abounds in the world. Green leafy vegetables constitute an in dispensable constituent of human diet in Africa generally and West Africa in particular (Osagie and Offiong, 1988). In addition, green leafy vegetables are used in the diets of postpartum women during which time it is claimed that they aid the contraction of the uterus.

However, low consumption of green leafy vegetables in diet is one of the major factor which leads to deficiency of vitamins and iron. There are some used and inexpensive leafy vegetables grown in Southeastern, Nigeria whose chemical and antinutritive potentials are yet to be adequately studied and utilized. Among these leaves are "Oha"(Pterocarpus soyauxii), "Ukazi" (Gnetum ofericanum), "Nchuanwu" (Ocimum viride), "Utabanzi" (Gongronema ratifolia), "Uziza" (Piper guinenses), and "Inene" (Amaranthus spinosus).

The present study therefore aimed at evaluating the levels of chemical composition and 
antinutrients in some commonly consumed tropical green leafy vegetables grown in southeastern, Nigeria.

\section{MATERIALS AND METHODS Source of material}

Six vegetable species used for this study include "Oha" (Pterocarpus soyauxii), "Ukazi" (Gnetum ofericanum), "Nchuanwu" (Ocimum viride), "Uziza" (Piper guinenses), "Utabanzi", (Gongronema ratifola) and "Inene" (Amaranthus Spinosus),. The leaves were collected from Okpuala Amapun, Isiala Ngwa North, Abia State, Nigeria and identified by a taxonomist $\mathrm{Mr}$. Ekwuno of the Forestry Department, Federal University of Agriculture, Makurdi, Nigeria.

\section{Preparation of samples}

The vegetable leaves used for the studies were harvested fresh, the leaves were destalked, washed with clean cold tap water and dried in an air draft oven (Model T12h, Genlab Wildness, U.K) at $60^{\circ} \mathrm{C}$ for $24 \mathrm{~h}$. After drying, the leaves were ground into a fine powder using a mortar and pestle sieved to pass a 40-mesh sieve and stored in air tight containers under refrigerated temperature for further use.

\section{Chemical analysis}

Moisture, protein, fat, crude fiber, carbohydrate, vitamin, iron, calcium, magnesium, phytic acid, oxalic acid, and tannin content were determined using the method of Association of Official Analytical Chemists (1984). Energy value was calculated using Atwater factor method $[(9 x$ fat $)+(4 x$ carbohydrate $)+(4 \mathrm{x}$ protein $)]$ as described by Osborne and Voogt (1978), and Ihekoronye and Ngoddy (1985).

\section{Statistical analysis}

All determinations were done in triplicate. Mean and standard deviations were calculated according to the method described by Steele and Torrie (1980) and data obtained were subjected to analysis of variance (ANOVA).

\section{RESULTS AND DISCUSSION}

The results of proximate composition of some green leafy vegetables grown in Southeastern, Nigeria is shown in Table 1. The moisture content of the six leafy vegetable ranged between 74.0 to $93 . \%$. Moisture content was significantly different $(\mathrm{p}<0.05)$ in all the six leafy vegetables. Protein value ranged between 1.50 to $2.20 \mathrm{~g} / 100 \mathrm{~g}$. There was no significant difference $(\mathrm{p}<0.05)$ in protein content among the leafy vegetables examined. Fat content varied from 0.80 to $1.30 \mathrm{~g} / 100 \mathrm{~g}$, without no significant difference $(p<0.05)$ among the leafy vegetables. Crude fibre ranged from 0.70 to $2.10 \mathrm{~g} / 100 \mathrm{~g}$. There was no significant difference $(p<0.05)$ in crude fibre among the leafy vegetables. Carbohydrate content ranged between 1.30 to $21.00 \mathrm{~g} / 100 \mathrm{~g}$. Carbohydrate content was significantly different $(\mathrm{p}<0.05)$ in all the six leafy vegetables. Energy value ranged between $12^{\mathrm{a}} .00$ to $97.00 \mathrm{keal} / 100 \mathrm{~g}$. There was significant difference $(p<0.05)$ in energy value among vegetable specie.

The micronutrient composition of some green leafy vegetables grown in Southeastern, Nigeria is shown in Table 2. Iron content varied from 16.16 to $23.03 \mathrm{mg}$. There was significant difference $(p<0.05)$ in iron content of the six leafy vegetables Calcium content ranged between 204.26 to $305.51 \mathrm{mg} / 100 \mathrm{~g}$, showing a significant difference $(\mathrm{p}<0.05)$ among the samples. Ascorbic acid ranged between 12.50 and $30.84 \mathrm{mg} / 100$. Considering the dailyrecommended intake of ascorbic acid ie 40mg, consumption of these green leafy vegetables in fresh form can provide the day's requirement of vitamin $\mathrm{C}$. There was significant difference $(p<0.05)$ in ascorbic acid content among samples. Magnesium value varied from 195.57 to $340.39 \mathrm{mg} / 100 \mathrm{~g}$, showing a significant difference $(\mathrm{P}<0.05)$ among samples. 
Table 3 shows the antinutrient composition of some green leafy vegetable grown in Southeast. Nigeria. Phytic acid values ranged between 37.90 to $68.50 \mathrm{mg} / 100 \mathrm{~g}$, showing a significant difference $(\mathrm{p}<0.05)$ among leafy vegetable Samples. Tannin content varies from 0.32 to 0.83 $\mathrm{mg} / 100 \mathrm{~g}$. There was no significant difference $(\mathrm{p}<0.05)$ in tannin content among samples. Oxalic acid content ranges between 24.65 to $46.22^{\mathrm{a}} \mathrm{mg} / \mathrm{g}$, showing a significant difference $(\mathrm{p}<0.05)$ among samples. Oxalic acid is known to interfere with calcium absorption by forming insoluble salts with calcium.

\section{CONCLUSION:}

It is believed that the results of this study will help to stimulate consumption or utilization of these leafy vegetables as they are good sources of micronutrients needed for healthy growth.

\section{REFERENCES:}

Akindahunsi, A.A and Salawu, S.O (2005).Phytochemical screening of nutrient and antinutrient composition of selected tropical green leafy vegetables. African J. Biotechnology 4(6): 497-501

Aletor, V.A and Adeogun, O.A (1995). Nutrients and antinutrient componets of some tropical leafy vegetables. Food Chem. 54(4): 375-379.

Osagie, A.U and Offiong, U.E (1988). Nutritional quality of plant food. Amik press, post harvest research unit, University of Benin, Benin City, Nigeria.
AOAC (1984).Association of official analytical Chemist. Official method of analysis (13th edition), Washington DC, USA.

Fasuyi, A.O (2006). Nutritional potentials of some tropical vegetable meals. chemical characterization and functional properties. African J. Biotechnology 5(1): 49-53.

Ihekoronye, A.I and Ngoddy, P.O (1985). Integrated food Science and technology for the tropics. Macmillian publisher, London p 257264.

Osborne, D.R and Voogt, P (1978). The analysis of nutrients in foods. Academic press, London p 128.

Steele, R.G and Torrie, J.H (1980). Principles and procedures of statistics (2nd edition) New York: McGraw Hill. 
Nutritive Evaluation of Some Tropical Leafy Vegetables

Chinma et al

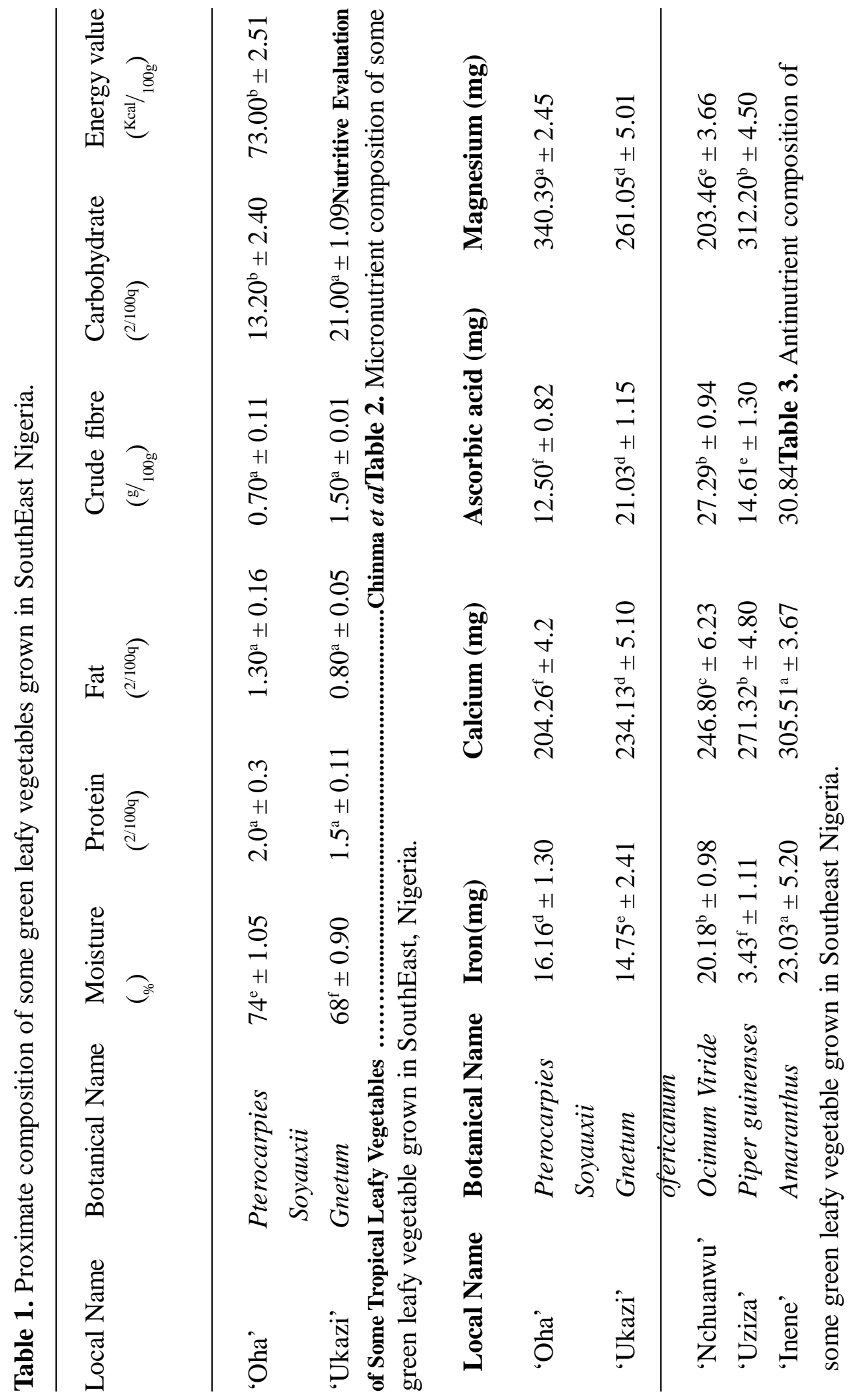




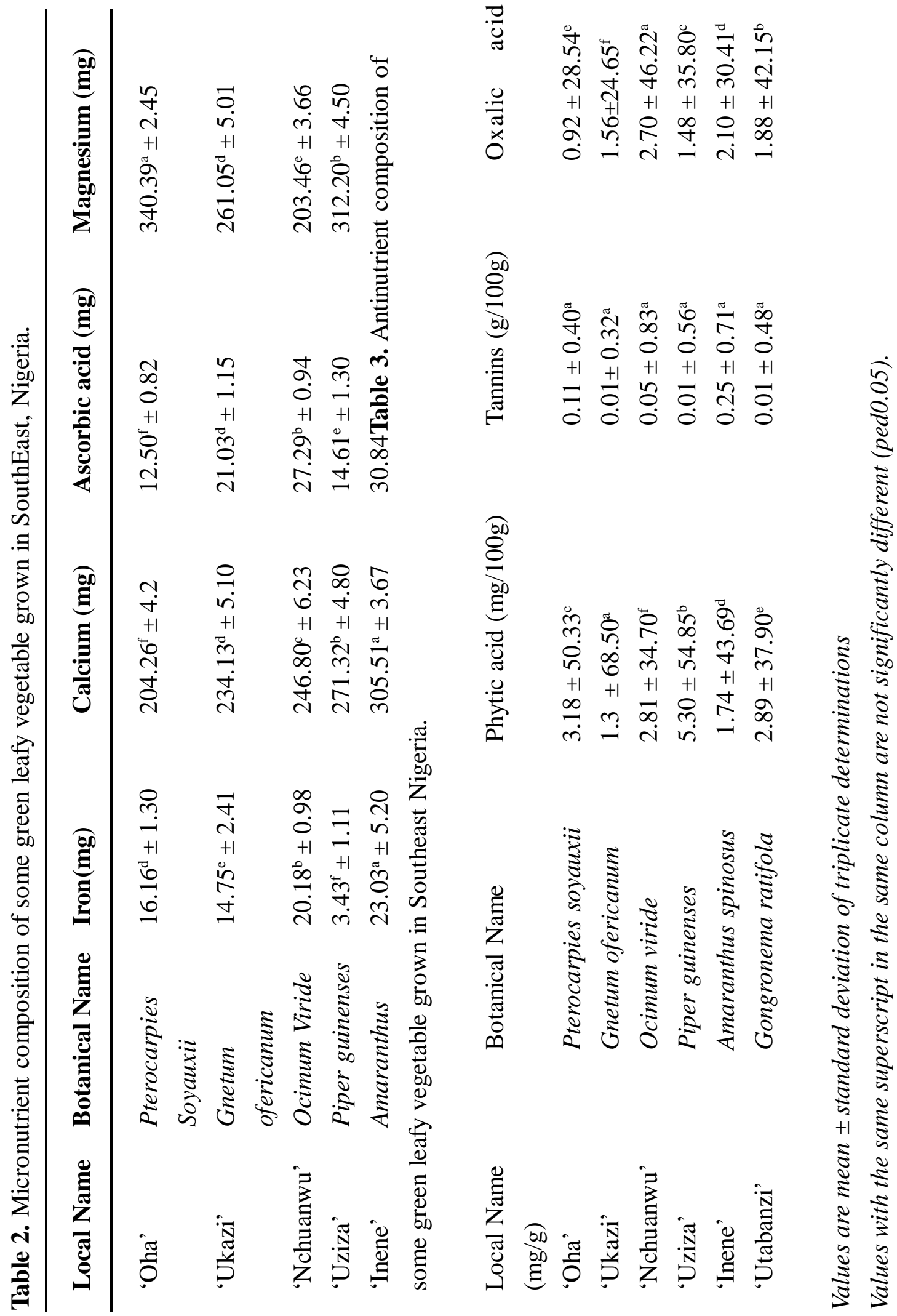




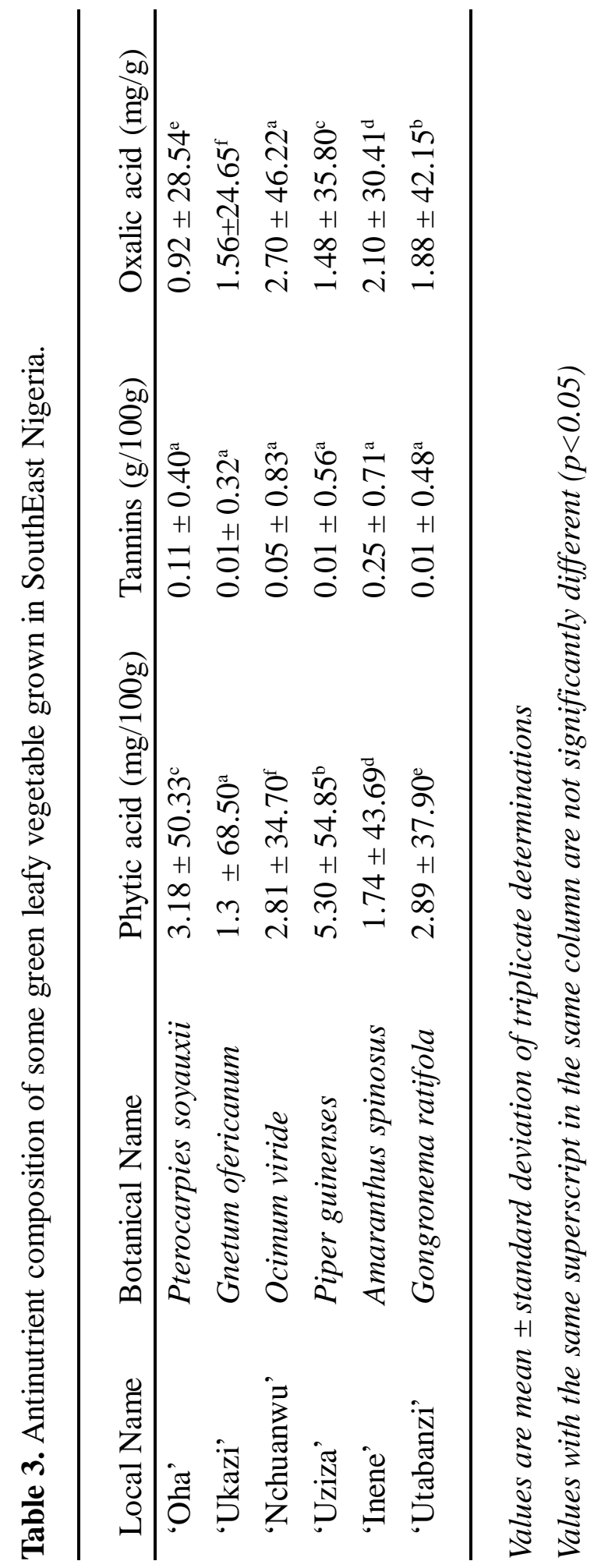

116 NIGERIAN FOOD JOURNAL, VOL. 25, No. 1, 2007 (www.ajol.info/journals/nifoj) ISSN 0189-7241 